Presented at the 1991 IEEE Nuclear Science Symposium,

Santa Fe, NM, November 5-9, 1991

BNL-46086

in.

Studies of the Dependence on Oxidation Thermal

Processes of Effects on the Electrical Properties

of Silicon Detectors by Fast Neutron Radiation*

\author{
Zheng $\mathrm{Li}$ and $\mathrm{H}$. W. Kraner \\ Brookhaven National Laboratory, Upion, NY 11973
}

November 1991

*This research was supported by the U. S. Department of Energy:

Contract No. DE-AC02-76CH00016. 


\title{
Studies of the Dependence on Oxidation Thermal Processes of Effects on the \\ Electrical Properties of Silicon Detectors by Fast Neutron Radiation
}

\author{
Zheng $\mathrm{Li}$ and $\mathrm{H}$. W. Kraner \\ BNL -46086 \\ Brookhaven National Laboratory, Upton, NY 11973 \\ DE92 007193
}

\begin{abstract}
High resistivity silicon detectors along with MOS capacitors made on five silicon dioxides with different thermal conditions $\left(975^{\circ} \mathrm{C}\right.$ to $\left.1200^{\circ} \mathrm{C}\right)$ have been exposed to fast neutron irradiation up to the fluence of a few timer $10^{14} \mathrm{n} / \mathrm{cm}^{2}$. New measurement techniques such as capacitance-voltage (CV) of MOS capacitors and current-voltage (I-V) of back to bick diodes $\left(\mathrm{p}^{+}-\mathrm{n}^{-}-\mathrm{p}^{+}\right.$if $\mathrm{n}^{-}$is not inverted to $\left.\mathrm{p}\right)$ or resistors $\left(p^{+}-p-p^{+}\right.$if inverted) have been introduced in this study in monitoring the possible type-inversion $(n \rightarrow p)$ under high neutron fluence. No type-inversion in the material underneath $\mathrm{SiO}_{2}$ and the $\mathrm{p}^{+}$contact has been observed so far in this work for detectors made on the five oxides up to the neutron fluence of a few times $10^{13} \mathrm{n} / \mathrm{cm}^{2}$. However, it has been found that detectors made on higher temperature oxides $\left(T \geq 1100^{\circ} \mathrm{C}\right)$ exhibit less leakage current increase at high neutron fluence ( $\phi$ $\left.\geq 10^{13} \mathrm{n} / \mathrm{cm}^{2}\right)$.
\end{abstract}

\section{INTRODUCTION}

Silicon detectors operated in a high fast neutron radiation environment are subject to several degradations of this performance. Deleterious effects include the increase of leakage current [1-4], frequency dependent capacitance-voltage (C-V) characteristics due to neutron induced deep levels [5], and dopant compensation or carrier removal [3,5-7]. In the currently designed SSC and LHC experimental environment: with $10^{34} \mathrm{~cm}^{2}-\mathrm{sec}$ beam luminosity, the annual fluence of fiut neutrons in the regions of silicon tracking detectors can be as high as $10^{14} \mathrm{n} / \mathrm{cm}^{2}$. With this fluence, the detector leakage current can go as high as $7 \mathrm{~mA} / \mathrm{cm}^{3}$, which would probably make room temperature (RT) operation impossible. The concentrations of various defect levels introduced by neutron displacement damage become much greater than initial dopant concentrations resulting in unpredictable detector behavior. One example of a concern of this kind has been the typeinversion of the bulk silicon material from n-type to p-type. This type-inversion would switch the location of the junction in a $p^{+}-n-n^{+}$junction diode detector from the front side $\left(p^{+}-n\right.$ before inversion) to the back side, $\left(\mathrm{p}-\mathrm{n}^{+}\right.$after inversion). Although the biasing polarity would not change in order to

*This research was supported by the U.S. Department of Energy: Contract No. DE-AC02-76CH00016. deplete the detector, the type inversion may cause major problems to the detector because the integrity of the would-be back side junction and its adjacent surfaces are not known initially and would remain obscure until type-inversion happens.

With or without explicit type inversion, another concern with high neutron fluence damage is that the eiectrical field in the silicon bulk may no longer be the linear field found from the simple solution of Poisson's equation or that described by the two (acceptor-like)-level model we proposed in Ref. [5]. A complicated field distribution in the bulk if donor-like and/or acceptor-like types of defect levels may become dominant in the positioning of the Fermi level at high neutron fluence (say $\phi_{\mathrm{n}} \geq 10^{13} \mathrm{n} / \mathrm{cm}^{2}$ ). A nonlinear or complicated Efield can cause charge collection problems and may make the $\alpha$-source charge collection measurement, which is now widely used to monitor the type-inversion [8], hard to interpret. Recent observations of the induced hole current pulse shape for front and back contact alpha response [9] have suggested a significant departure from linear E-fields in devices irradiated to $5 \times 10^{13} \mathrm{n} / \mathrm{cm}^{2}$.

\section{EXPERIMENTAL DETAILS}

Silicon materials used in this study are Wacker and Topsil $\langle 111\rangle$ wafers, with resistivity ranging from $2-10 \mathrm{k} \Omega \mathrm{cm}$. Five different oxidation processes were used to oxidize these Si wafers. Table I lists the details of each oxidation process. High temperature oxidations were used to increase the oxygen concentration in FZ-Si to about $10^{16}$ to $10^{17} \mathrm{~cm}^{3}$ [10]. Detector fabrication processing steps are the same for various groups of silicon wafers except different oxidation conditions. Detectors in this study are ion implanted $p^{+} / n^{\prime} / n^{+}$structures. Fast neutrons with the energy from $10 \mathrm{keV}$ to $2.2 \mathrm{MeV}$, and an average of $\overline{\mathrm{E}}=1 \mathrm{MeV}$ are from a van de Graaff accelerator at University of Lowell. Details of the source have been given elsewhere [5]. C-V and I-V measurements at various neutron fluences were made in consecutive neutron exposures within ten hours with the time gap between each exposure for measurement of less than 30 minutes.

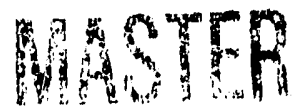

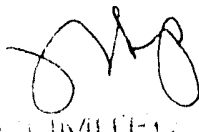


Table I. Thermal Conditions for Various Oxidation Processes

\begin{tabular}{|c|c|c|c|c|c|}
\hline $\begin{array}{l}\text { Name of } \\
\text { the Oxide }\end{array}$ & $\begin{array}{l}\text { Oxide C } \\
\left(1100^{\circ} \mathrm{C}\right)\end{array}$ & $\begin{array}{l}\text { Oxide } A^{\prime} \\
\left(975^{\circ} \mathrm{C}\right)\end{array}$ & $\begin{array}{l}\text { Oxide A } \\
\left(975^{\circ} \mathrm{C}\right)\end{array}$ & $\begin{array}{l}\text { Oxide A } \\
\left(1200^{\circ} \mathrm{C}\right)\end{array}$ & $\begin{array}{l}\text { Oxide } \mathrm{A}^{\prime} \\
\left(1200^{\circ} \mathrm{C}\right) \\
\left(\text { in } \mathrm{TCA} / \mathrm{O}_{2}\right)\end{array}$ \\
\hline $\begin{array}{l}\text { Thermal } \\
\text { conditions }\end{array}$ & $\begin{array}{l}6 \mathrm{hr}, 1100^{\circ} \mathrm{C} \text { in } \mathrm{TCA} / \mathrm{O}_{2} \\
18 \mathrm{hr}, 700^{\circ} \mathrm{C} \text { in } \mathrm{TCA} / \mathrm{O}_{2} \\
4 \mathrm{hr}, 1000^{\circ} \mathrm{C} \text { in } \mathrm{TCA} / \mathrm{O}_{2} \\
2 \mathrm{hr}, 1000^{\circ} \mathrm{C} \text { in } \mathrm{N}_{2}\end{array}$ & $\begin{array}{l}18 \mathrm{hr}, 975^{\circ} \mathrm{C} \text { in } \mathrm{TCA} / \mathrm{O}_{2} \\
2 \mathrm{hr}, 975^{\circ} \mathrm{C} \text { in } \mathrm{N}_{2}\end{array}$ & $\begin{array}{l}18 \mathrm{hr}, 975^{\circ} \mathrm{C} \text { in } \mathrm{O}_{2} \\
2 \mathrm{hr}, 975^{\circ} \mathrm{C} \text { in } \mathrm{N}_{2}\end{array}$ & $\mid \begin{array}{l}20 \mathrm{hr}, 1200^{\circ} \mathrm{C} \text { in } \mathrm{O}_{2} \\
2 \mathrm{hr}, 1000^{\circ} \mathrm{C} \text { in } \mathrm{N}_{2}\end{array}$ & $\begin{array}{l}20 \mathrm{hr}, 1200^{\circ} \mathrm{C} \\
2 \mathrm{hr}, 1000^{\circ} \mathrm{C}\end{array}$ \\
\hline $\begin{array}{l}\text { Oxide } \\
\text { thickness }\end{array}$ & $4500 \AA$ & $2800 \AA$ & $2800 \AA$ & $9000 \AA$ & $\begin{array}{l}\text { Bad oxide MOS-CV } \\
\text { impossible }\end{array}$ \\
\hline
\end{tabular}

*TCA: Trichlorethane

\section{RESULTS AND DISCUSSION}

\section{A. MOS Capacitor Measurements}

For control purposes, $\mathrm{C}(\mathrm{V})$ characteristics of MOS capacitors made on n-type and p-type Si substrates before neutron radiation are shown in Fig. 1. It is clear that for ntype substrate, electrons accumulate underneath $\mathrm{SiO}_{2}$ at positive gate bias and for p-type substrate, holes accumulate underneath $\mathrm{SiO}_{2}$ at negative gate bias. The flatband voltage shifts $\left(\Delta \mathrm{V}_{\mathrm{FB}}\right)$ are always negative for both types of substrates due to the positive charge in the $\mathrm{SiO}_{2}$.

MOS CAPACITOR before n-rad.

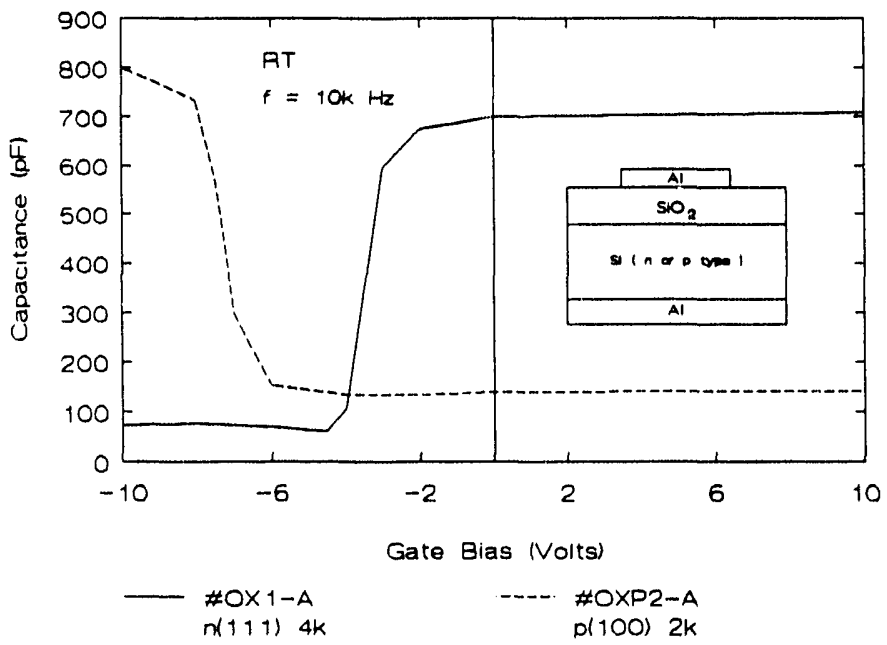

Fig. 1. C-V Characteristics of $\mathrm{Al} / \mathrm{SiO}_{2} / \mathrm{n}-\mathrm{Si}$ and P-Si MOS Capacitors Before Neutron Radiation.

$\mathrm{C}(\mathrm{V})$ data of MOS capacitors made on oxide $\mathrm{C}\left(1100^{\circ} \mathrm{C}\right)$ exposed to consecutive neutron fluences of up to $2 \times 10^{13}$ $\mathrm{n} / \mathrm{cm}^{2}$ are shown in Fig. 2. It is clear that $\mathrm{C}(\mathrm{V})$ characteristics of this capacitor still exhibit the behavior of the n-type substrate, since it is the electrons that are accumulated at the positive bias, i.e. electron is still majority underneath the $\mathrm{SiO}_{2}$ layer. The lower of the capacitance at accumulation $\left(\mathrm{V}_{\mathrm{g}}>\right.$ $0), C_{c a}$, is due to the increase of series resistance resulting from neutron induced donor removal (formation of $\mathrm{V}-\mathrm{P}$

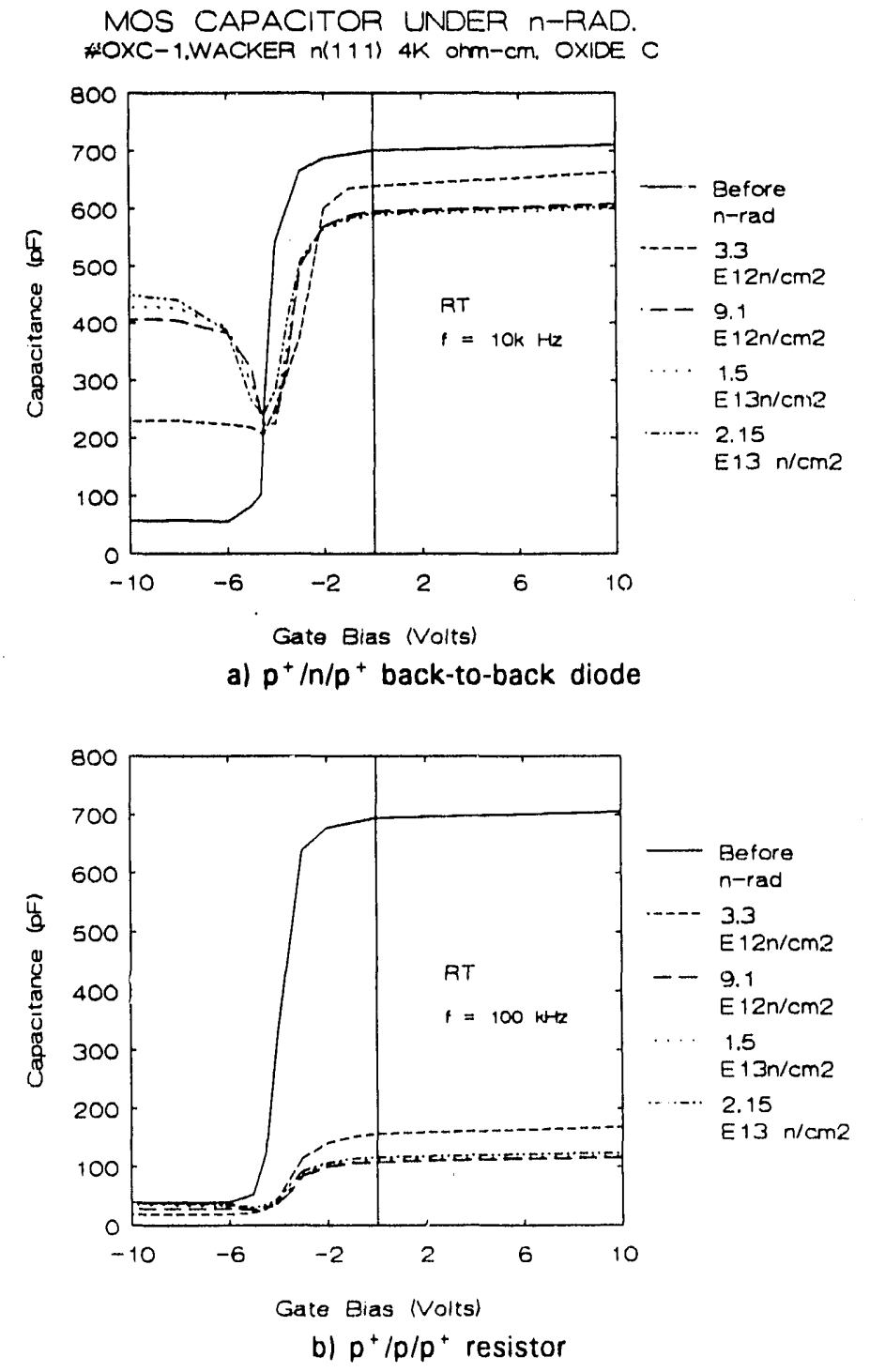

Fig. 2. C-V Characteristics of an $\mathrm{Al} / \mathrm{SiO}_{2} / \mathrm{n}-\mathrm{Si} \mathrm{MOS}$ Capacitor After Consecutive Neutron Radiations $U p$ to $2.2 \times 10^{13}$ $\mathrm{n} / \mathrm{cm}^{2} . \mathrm{SiO}_{2}$ Here Is Oxide $\mathrm{C}\left(1100^{\circ} \mathrm{C}\right)$

centers) and/or formation of acceptor-like levels. As it is shown in Fig. 3, this effect is minimum at low frequencies. 
The increase of minority carrier response (at $V_{B}<0$ ) at a given frequency is due to the degradation of minority carrier generation life time resulting from the neutron induced generation recombination centers. The transition frequency for minority carrier to response is found proportional inversely to the minority carrier life-time [11]. We note that there is no flatband shift after neutron radiation.

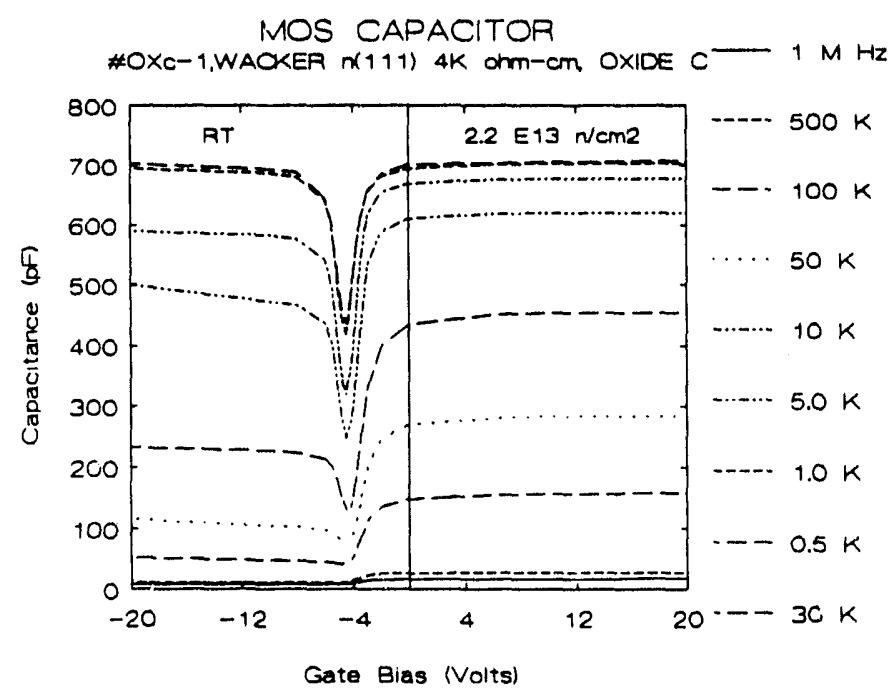

Fig. 3. I-V characteristics of the back-to-back diode configuration with $\mathrm{SiO}_{2}$ on the back side after n-radiation. Detectors are made on Oxide $\mathrm{C}\left(1100^{\circ} \mathrm{C}\right)$.

C(V) characteristics of MOS capacitors made on Oxide A $\left(975^{\circ}\right)$ and Oxide $A^{\prime}\left(975^{\circ} \mathrm{C}\right)$ irradiated to consecutive neutron fluences up to $2.5 \times 10^{13} \mathrm{n} / \mathrm{cm}^{2}$ are shown in Figs. 4 and 5 , respectively. Again, no sign of substrate change from n-type to p-type is seen here, although there is a slight difference in $\mathrm{C}-\mathrm{V}$ behavior under neutron radiation between Oxide $\mathrm{C}$ $\left(1100^{\circ} \mathrm{C}\right)$ and Oxide $\mathrm{A}\left(975^{\circ} \mathrm{C}\right)$ or Oxide $\mathrm{A}^{\prime}\left(975^{\circ} \mathrm{C}\right)$.

Figure 6 shows $\mathrm{C}(\mathrm{V})$ characteristics of a MOS capacitor made on Oxide $\mathrm{A}\left(1200^{\circ} \mathrm{C}\right)$ with various fluence of neutron radiation. The $\mathrm{C}-\mathrm{V}$ behavior suggest that the substrate becomes close to intrinsic after neutron radiation to $1.3 \times 10^{13}$ $\mathrm{n} / \mathrm{cm}^{2}$. However, we note that since this oxide is very thick $\left(\mathrm{d}_{\alpha x} \sim 1 \mu \mathrm{m}\right) . \quad C_{\alpha x}=\varepsilon_{0} \varepsilon_{\alpha x} / d_{\alpha x}^{\prime}$. Area is very small to begin with, and the difference between $C_{\alpha x}$ and $C_{\min }$ is small, so one can hardly resolve $\mathrm{C}_{\alpha x}$ and $\mathrm{C}_{\min }$ after radiation, even though the substrate beneath $\mathrm{SiO}_{2}$ miny still be n-type.

The capacitors shown above are all made of Wacker $\mathrm{n}\langle 111\rangle, 4 \mathrm{k} \Omega \mathrm{cm}$ wafers with different oxidation conditions. Data shown in Fig. 2 through Fig. 6 demonstrates that different oxidation temperatures $\left(975^{\circ}\right.$ to $\left.1200^{\circ} \mathrm{C}\right)$ affect little in terms of nuterial type beneath the $\mathrm{SiO}_{2}$ layer after neutron radiations. Figure 7 shows the $\mathrm{C}-\mathrm{V}$ data of a MOS capacitor made of Topsil $n\langle 111\rangle, 2-4 \mathrm{k} \Omega \mathrm{cm}$ wafer with Oxide $C$ $\left(1100^{\circ} \mathrm{C}\right)$. It is clear that this MOS capacitor still exhibits classical $n$-type behavior after being neutron irradiated to about $2.3 \times 10^{13} \mathrm{n} / \mathrm{cm}^{2}$, and material difference also affects little on this behavior.

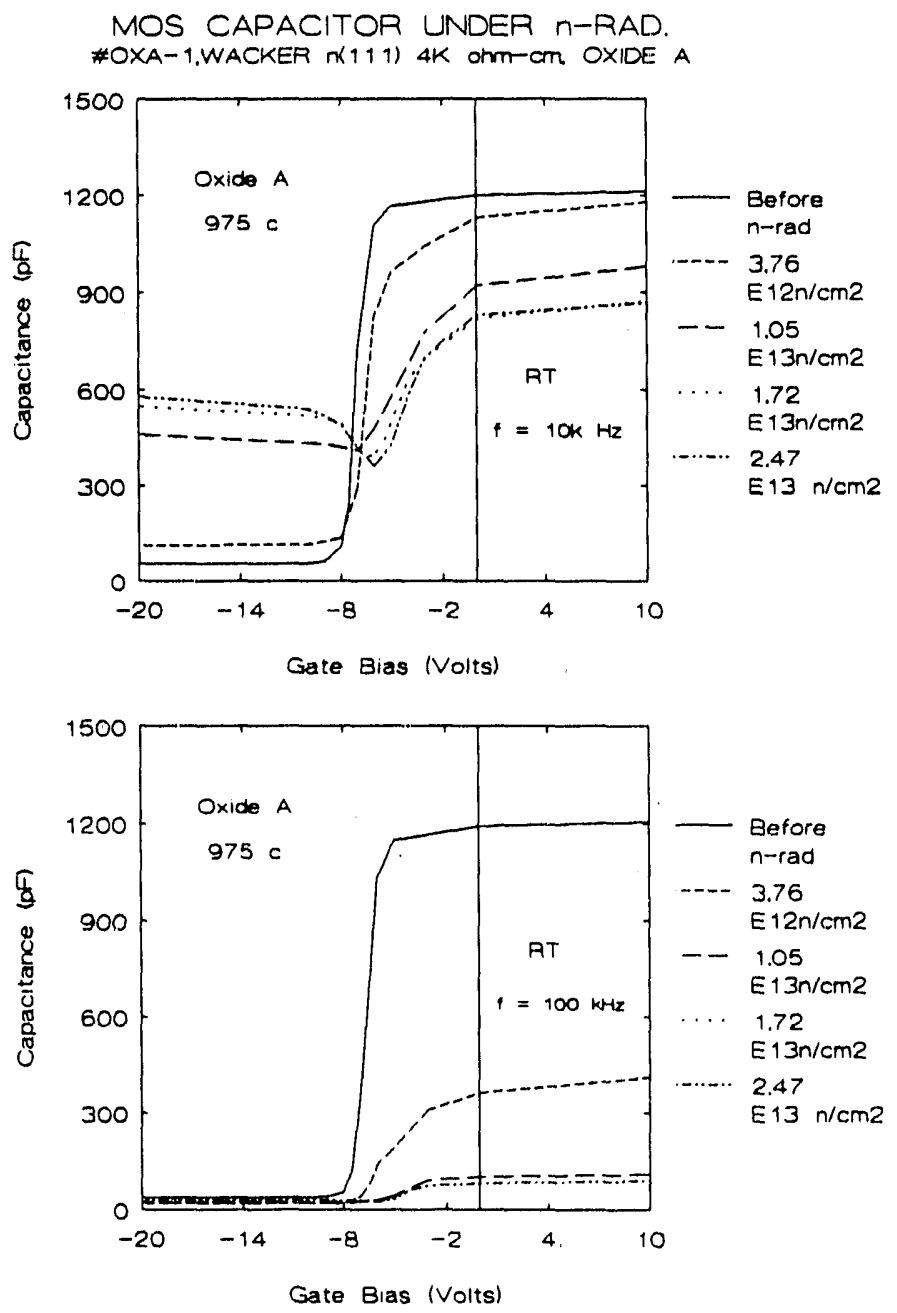

Fig. 4. C-V characteristics of an $\mathrm{Al} / \mathrm{SiO}_{2} / \mathrm{n}-\mathrm{Si} \mathrm{MOS}$ capacitor after consecutive neutron radiations up to $2 \times 10^{13} \mathrm{n} / \mathrm{cm}^{2}$. $\mathrm{SiO}_{2}$ here is Oxide $\mathrm{A}\left(975^{\circ} \mathrm{C}\right)$.

\section{B. Back-to-back Diode Measurements}

Back-to-back diode $\left(p^{+} / \mathbf{n} / \mathbf{p}^{+}\right)$I-V characteristics of a detector before neutron radiation are shown in Fig. 8a. Figure $8 \mathrm{~b}$ shows the resistor behavior of $\mathrm{a} \mathrm{p}^{+} / \mathrm{p} / \mathrm{p}^{+}$structure. The difference between the two structures $\left(\mathrm{p}^{+} / \mathrm{n}_{\mathrm{n}} / \mathrm{p}^{+}\right.$and $\left.\mathrm{p}^{+} / \mathrm{p} / \mathrm{p}^{+}\right)$ is clear.

I-V characteristics of back-to-back structures of $p^{+}-n$ junction detectors made on various oxides after being radiated to about $2 \times 10^{13} \mathrm{n} / \mathrm{cm}^{2}$ still exhibit back-to-back diode characteristics. As it is shown, for example, in Fig. 9 (low temperature oxide) and Fig. 10 (high temperature oxide), depending on the sign of the bias on the guard ring (GR), one measures a $\mathrm{p}^{+} / \mathrm{n}$ junction either on the detector side or on the GR side.

However, as Hall pointed out [12], if the substrate were inverted to p-type, the total current in the back-to-back I-V measurement would have a component that is the reverse current of the junction $\mathrm{p} / \mathrm{n}^{+}$from the back side of the detector. So dapending on the relative magnitudes of this current 
component and the resistive current component $\left(\mathrm{p}^{+} / \mathrm{p} / \mathrm{p}^{+}\right)$, one may measure one current component or the other. Data shown in Fig. 11, however, rules out this possibility. Here a $\mathrm{p}^{+} / \mathrm{n} / \mathrm{SiO}_{2}$ structure $\left(\mathrm{no} \mathrm{n}^{+}\right.$) was irradiated to $1.2 \times 10^{13} \mathrm{n} / \mathrm{cm}^{2}$ and back-to-back I-V's still exhibit $\mathbf{p}^{+} / \mathbf{n} / \mathbf{p}^{+}$characteristics. This suggests that a $p^{+} / \mathbf{n}$ junction is always preserved in the front side of the detector after n-radiation.

MOS CAPACITOR UNDER n-RAD.

\#OXA'-1,WACKEF $N(111) 4 K$ otm-cmOXIDE $A$
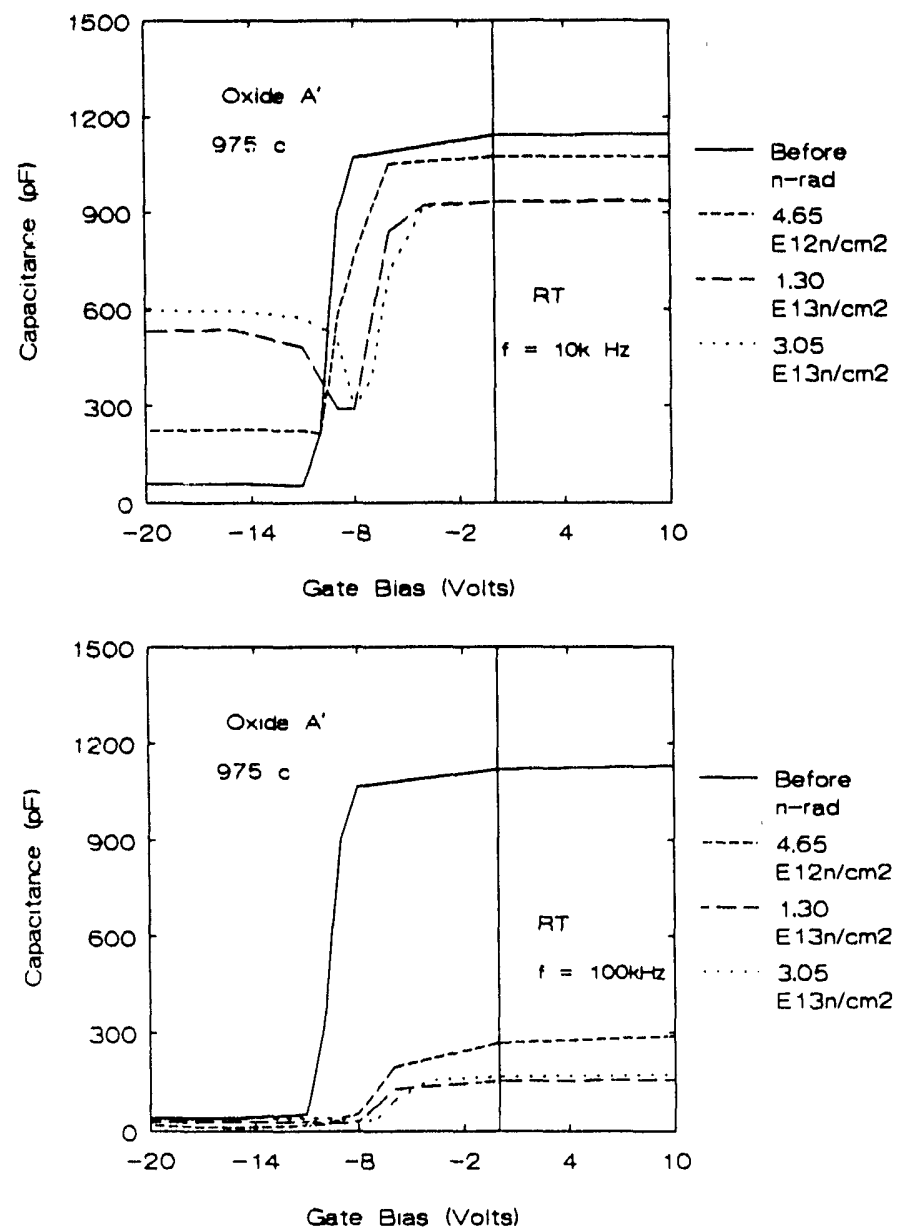

Fig. 5. C-V characteristics of an $\mathrm{A} V / \mathrm{SiO}_{2} / \mathrm{n}-\mathrm{Si}$ MOS capacitor after consecutive neutron radiations up to $3.1 \times 10^{13} \mathrm{n} / \mathrm{cm}^{2}$. SiO $\mathrm{O}_{2}$ here is Oxide $\mathrm{A}^{\prime}\left(975^{\circ} \mathrm{C}\right)$.

We note that both the MOS capacitor data and $\mathrm{p}^{+} / \mathbf{n} / \mathrm{p}^{+}$ back-to-back diode data only show the existence of a rectifying junction on the front side and nothing can be told on the back side of the detector. In fact, our $\alpha$-source current pulse measurement have revealed the formation of the E-field (or rectifying junction) at about $8 \times 10^{12} \mathrm{n} / \mathrm{cm}^{2}$ on the back side of detector $[9,13]$. As the $\phi_{n}$ goes further up, the E-fields found to be confined near both front and back contacts leaving the near intrinsic bulk with little or no field. A model of $\mathrm{p}^{+} / \mathrm{n} / \mathrm{i} / \mathrm{p} / \mathbf{n}^{+}$structure after high does of neutron radiation $\left(\phi_{\mathrm{n}}\right.$ $\left.\geq 10^{13} \mathrm{n} / \mathrm{cm}^{2}\right)$ has been proposed in Ref. $[9,13]$. In this model, the Fermi level is pinned around the middle of the energy band gap' and the E-field is controlled by the deep donor-like and acceptor-like levels that cross the Fermi level.

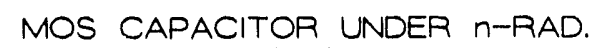

\#OXA2-2.WACKER $\mathrm{m}(111)$ $4 \mathrm{~K}$ otm-CmOXIDE A
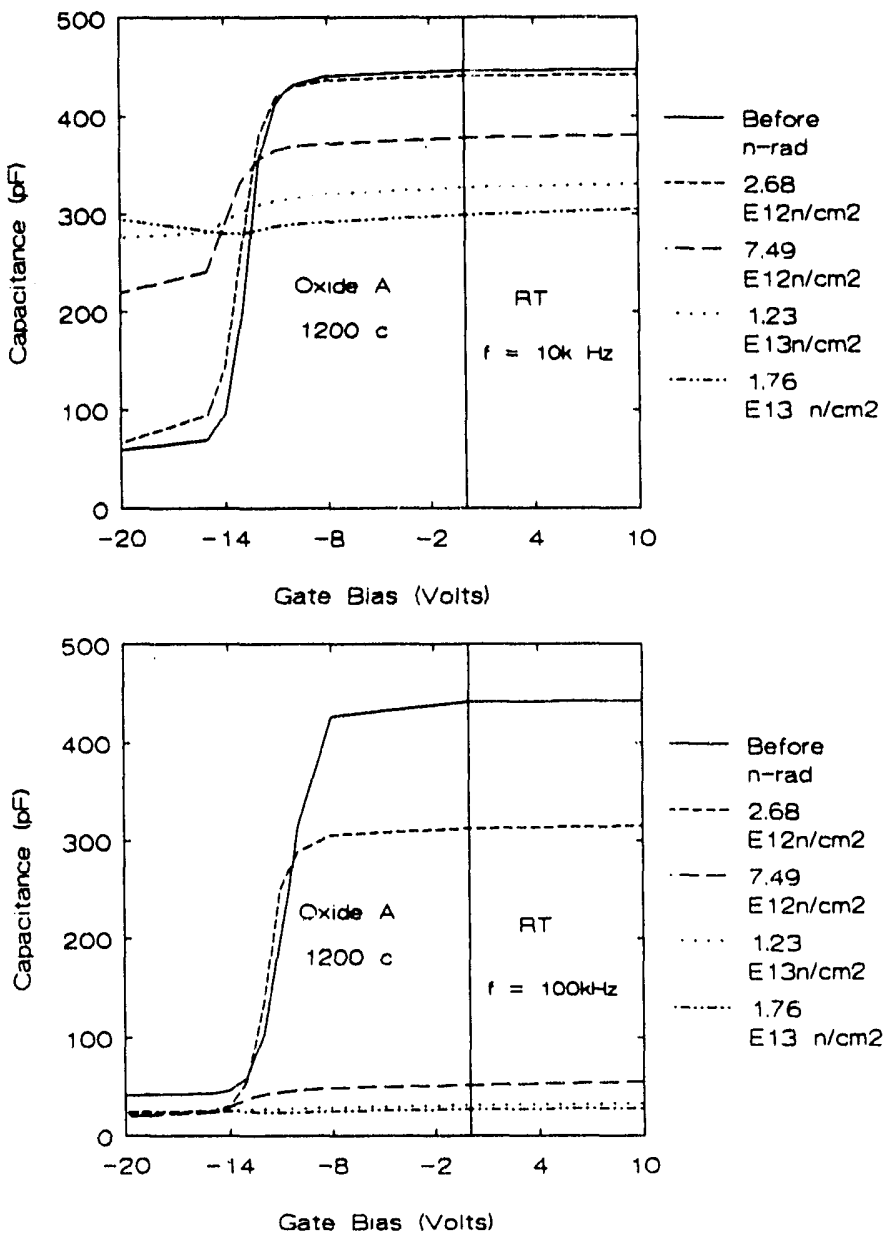

Fig. 6. $\mathrm{C}-\mathrm{V}$ characteristics of an $\mathrm{Al} / \mathrm{SiO}_{2} / \mathrm{n}-\mathrm{Si}$ MOS capacitor after consecutive neutron radiations up to $1.8 \times 10^{13} \mathrm{n} / \mathrm{cm}^{2}$. $\mathrm{SiO}_{2}$ here is Oxide $\mathrm{A}\left(1200^{\circ} \mathrm{C}\right)$.

\section{Leakage Current Measurements}

$\mathrm{p}^{+} / \mathbf{n} / \mathbf{n}^{+}$implanted junction diode detectors made on various oxides were also exposed consecutively to neutron radiation to study the dependence of leakage current coefficient (or damage coefficient) $\alpha\left(\Delta \mathrm{I}=\alpha \mathrm{V} \phi_{\mathrm{n}}, \mathrm{V}\right.$ is the depleted volume) as a function of detector processing and material parameters. The damage coefficients have been normalized to $20^{\circ} \mathrm{C}$ and the RT anneal was kept at minimum. The total neutron fluences for the detectors in the damage coefficient study were less than $5 \times 10^{12} \mathrm{n} / \mathrm{cm}^{2}$.

Table II lists the damage coefficients for various oxidation processes. The damage coefficients are all about $7 \times 10^{-17}$ $\mathrm{A} / \mathrm{cm}$ and Oxide $\mathrm{A}\left(1200^{\circ} \mathrm{C}\right)$ is not any rad-harder than Oxide A $\left(975^{\circ} \mathrm{C}\right)$ or Oxide $A^{\prime}\left(975^{\circ} \mathrm{C}\right)$. This indicates that at low neutron fluences (say $\phi_{\mathrm{n}}<10^{13} \mathrm{n} / \mathrm{cm}^{2}$ ) oxygen in the silicon does not necessarily play a significant role. This point is also supported by the data shown in Table II on $\mathrm{FZ}$ and $\mathrm{CZ}$ silicon 
detectors, where damage coefficient were found virtually the same for the two materials with vastly different oxygen concentrations. At higher neutron fluences $\left(\phi_{n}>10^{13} \mathrm{n} / \mathrm{cm}^{2}\right)$, detectors made on high temperature oxides $\left(\mathrm{T}>1000^{\circ} \mathrm{C}\right.$ ) yield less leakage or generation current than those from low temperature oxides. This seems to suggest that an excess of oxygen does getter vacancies significantly at high neutron fluence. One must exercise caution here though, since the data shown in Fig. 12 are only from one set of samples and more sets of samples may be needed to verify this effect.

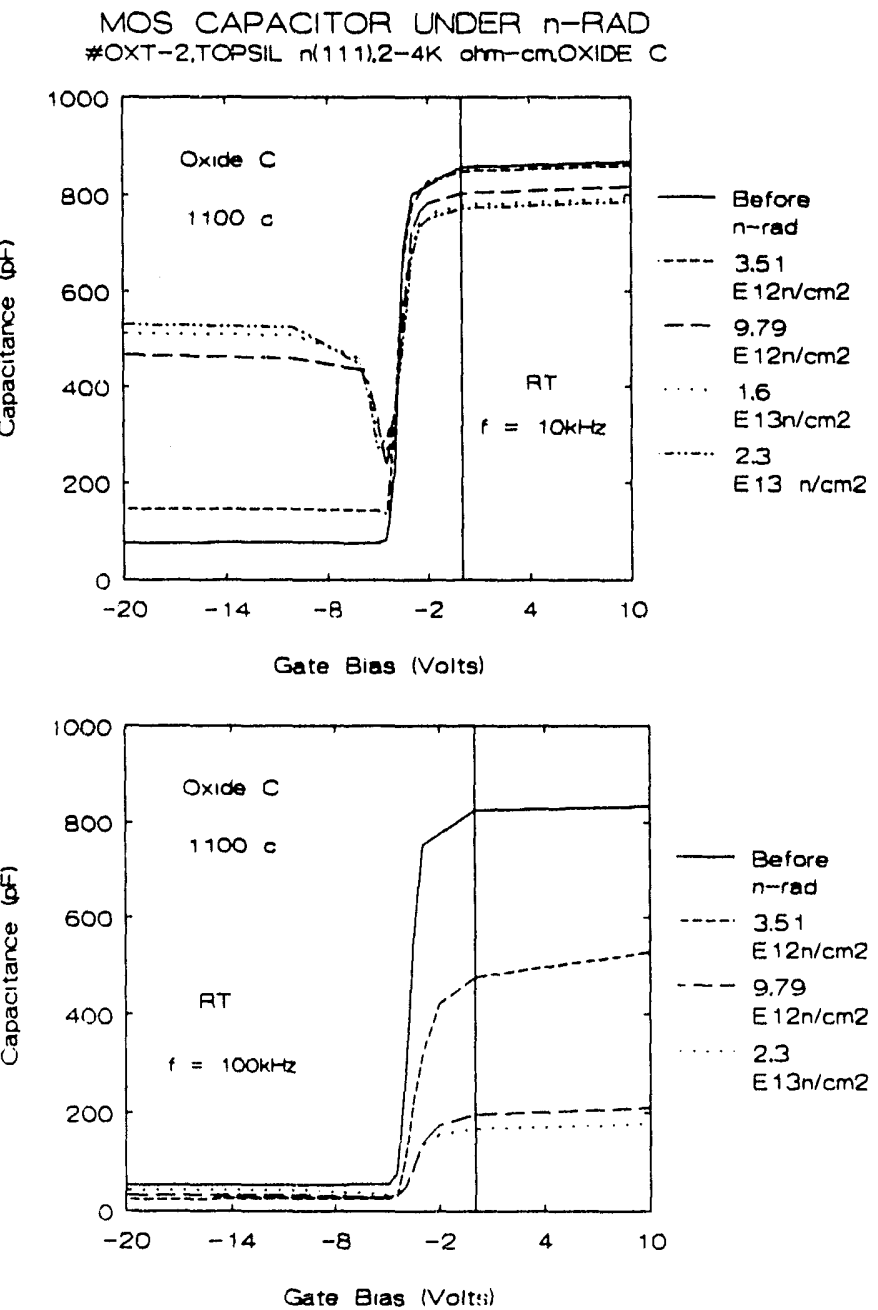

Fig. 7. C-V characteristics of an $\mathrm{Al} / \mathrm{SiO}_{2} / \mathrm{n}-\mathrm{Si}$ MOS capacitor after consecutive neutron radiations up to $2.3 \times 10^{13} \mathrm{n} / \mathrm{cm}^{2}$. $\mathrm{SiO}_{2}$ here is Oxide $\mathrm{C}\left(1100^{\circ} \mathrm{C}\right)$ and $\mathrm{Si}$ wafer is from Topsil.

An explanation for the different oxygen behaviors in low and high neutron fluence domains may be that the rate-limit step for the formations of $\mathrm{O}-\mathrm{V}(\mathrm{A})$ centers is related to the vacancy in terms of vacancy availability and/or vacancy mobility, rather than oxygen concentration. As a result, the introduction rates for $\mathrm{O}-\mathrm{V}$ (A) center are the same at low neutron fluences for both silicon materials with low and high oxygen concentrations. However, as the $\phi_{n}$ increases, $\mathrm{O}-\mathrm{V}$ concentration will saturate at much lower $\phi_{n}$ in Si with low oxygen concentration than that in $\mathrm{Si}$ with high oxygen concentration, and the difference between the two materials begins to show un at high neutron fluence. Only then the excess oxygen in slicon with high oxygen concentrations may act as getters for vacancies.

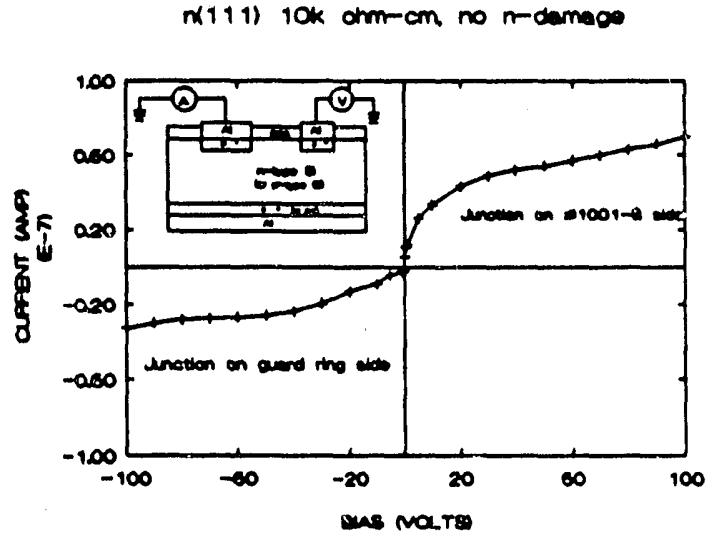

a) $\mathrm{p}^{+} / \mathrm{n} / \mathrm{p}^{+}$back-to-back diode

w60-2. 1111$)$ Skorm-an, no n-chamage

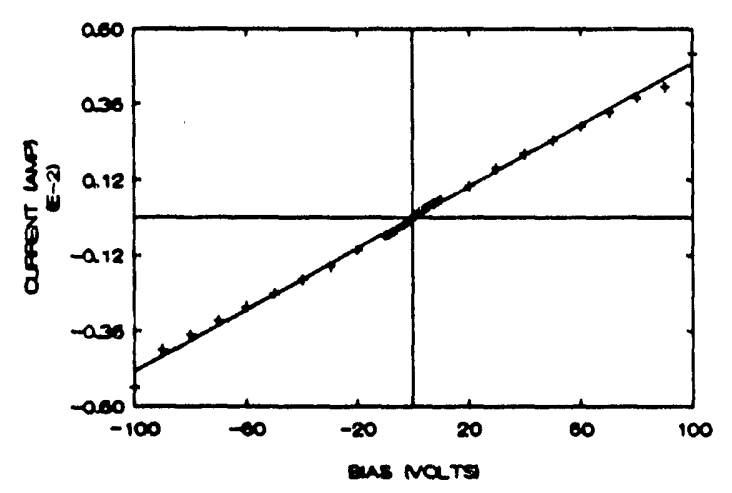

b) $\mathrm{p}^{+} / \mathrm{p} / \mathrm{p}^{+}$resistor

Fig. 8. I-V characteristics of a) back-to-back diode $\left(\mathrm{p}^{+} / \mathrm{n}^{-} / \mathrm{p}^{+}\right)$and b) resistor $\left(\mathrm{p}^{+} / \mathrm{p}^{-} / \mathrm{p}^{+}\right)$before neutron radiacion.

BACK TO BACK DIODE I-V CHARACTERISTICS \#133-2, Wacker n(111) 4k orm-cm

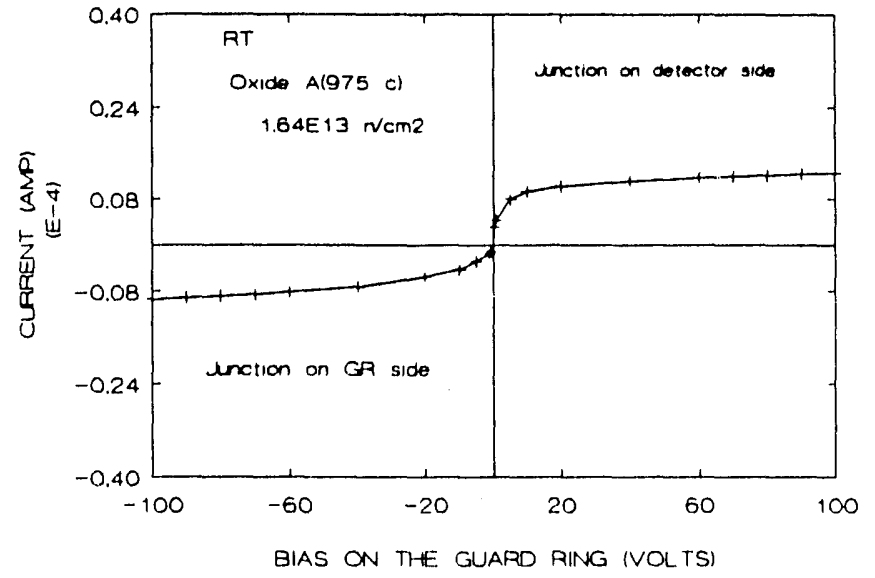

Fig. 9. Back-to-back diode I-V characteristics of a detector made on OX3 (Oxide $A\left(995^{\circ} \mathrm{C}\right)$ ) after neutron radiation up to $2 \times$ $10^{13} \mathrm{n} / \mathrm{cm}^{2}$. 
BACK TO BACK DIODE I-V CHARACTERISTICS *135. Wacker $n(111) 4 \mathrm{k} \mathrm{om-cm}$

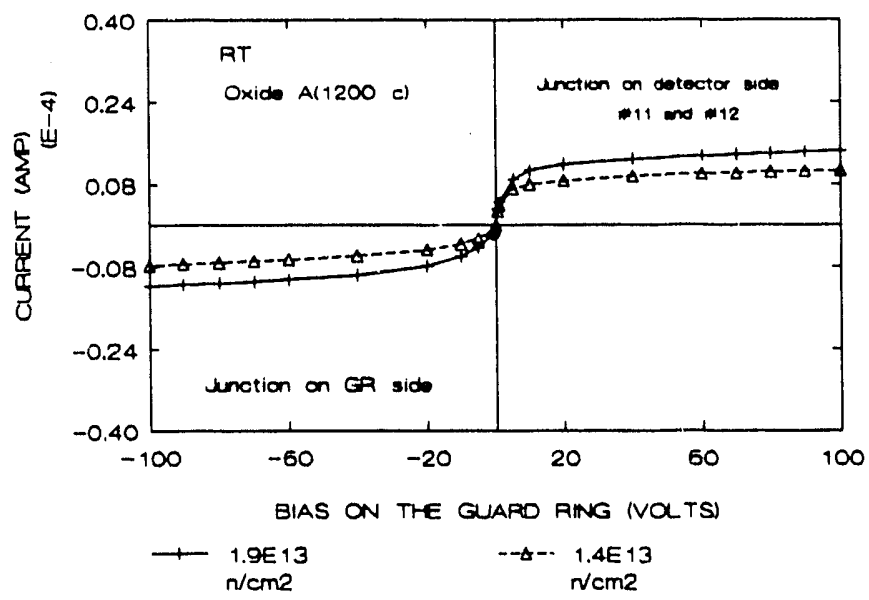

Fig. 10. Back-to-back diode I-V characteristics of a detector made on Oxide $A\left(1200^{\circ} \mathrm{C}\right)$ after neutron radiation up to $2 \times$ $10^{13} \mathrm{n} / \mathrm{cm}^{2}$. $p+/ n / S I O 2$ STRUCTURE UNDER n-RADIATION \#194:D+/n/p+. .n(1111) 4 kom-cm

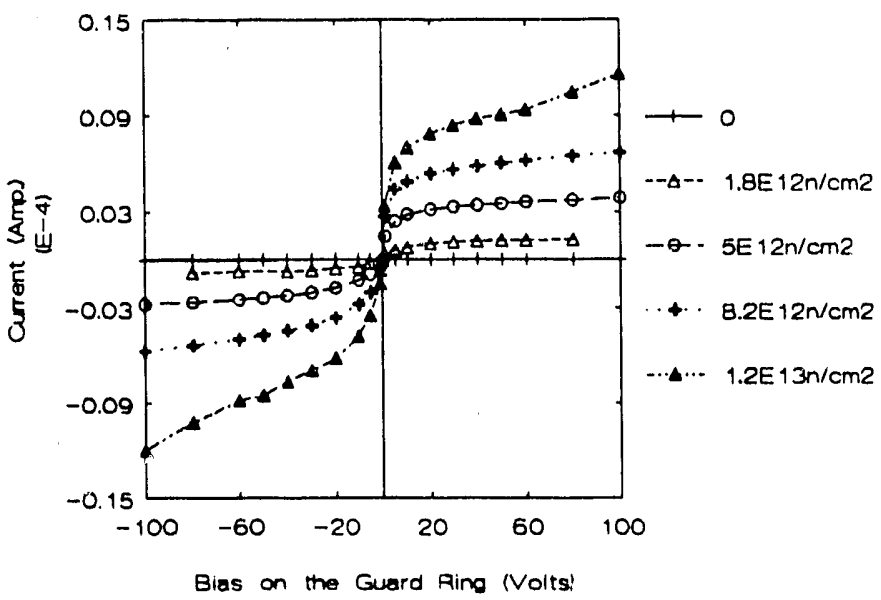

Fig. 11. Back-to-back I-V characteristics of a $\mathrm{p}^{+} / \mathrm{n} / \mathrm{SiO}_{2}$ structure made on Oxide $C\left(1100^{\circ} \mathrm{C}\right)$ after neutron radiation up to 2 $\times 10^{13} \mathrm{n} / \mathrm{cm}^{2}$.

Table II. Damage Coefficient $\alpha\left(A \mathrm{~cm}^{-1}\right)$

\begin{tabular}{|c|c|c|c|c|}
\hline \multicolumn{5}{|c|}{ Sample and Processing } \\
\hline Sample & Material & Depletion $w(v) \mu \mathrm{m}$ & Process & $\alpha\left(\times 10^{.16} \mathrm{~A} / \mathrm{cm}\right)$ \\
\hline $128-10$ & Wacker n FZ <111> $4 \mathrm{~K}$ & $302(60)$ & Oxide $\mathrm{A}^{\prime}\left(975^{\circ} \mathrm{C}\right)$ & $0.71 \pm .07$ \\
\hline $133-9$ & Wacker n FZ $<111>4 \mathrm{~K}$ & $300(60)$ & Oxide A $\left(975^{\circ} \mathrm{C}\right)$ & $0.75 \pm .07$ \\
\hline $135-8$ & Wacker n FZ $<111>4 \mathrm{~K}$ & $312(60)$ & Oxide $\mathrm{A}\left(1200^{\circ} \mathrm{C}\right)$ & $0.75 \pm .07$ \\
\hline $130-10$ & Wacker n FZ $<111>4 \mathrm{~K}$ & $300(60)$ & Oxide $\mathrm{C}\left(1100^{\circ} \mathrm{C}\right)$ & $0.62 \pm .06$ \\
\hline $107-11$ & Wacker n FZ $<111>2-4 \mathrm{~K}$ & $375(80)$ & Oxide C $\left(1100^{\circ} \mathrm{C}\right)$ & $0.67 \pm .07$ \\
\hline $81-10$ & $\begin{array}{l}\text { Virginia Semiconductor } \\
\text { n FZ }<111>220 \mathrm{~K}\end{array}$ & $58(60)$ & Oxide $\mathrm{C}\left(1100^{\circ} \mathrm{C}\right)$ & $0.45 \pm 0.1$ \\
\hline $77-11$ & $\begin{array}{l}\text { Virginia Semiconductor } \\
\mathrm{n} \mathrm{CZ}<111>130 \mathrm{~K}\end{array}$ & $45(60)$ & Oxide $\mathrm{C}\left(1100^{\circ} \mathrm{C}\right)$ & $0.47 \pm 0.1$ \\
\hline
\end{tabular}

\section{CONCLUSION}

We have introduced two independent measurement techniques to effectively monitor the material type underneath the $\mathrm{SiO}_{2}$ layer or the $\mathrm{p}^{+}$contact during the neutron radiation. No type change near the front contact has been observed up to the neutron fluence of about a few $\times 10^{13} \mathrm{n} / \mathrm{cm}^{2}$ in this study. These two techniques however give no information about the electrical field structure on the back side $\left(n^{+}\right.$side) of the detector, which with our $\alpha$-source current pulse measurements, has been found to become rectifying (i.e., $\mathrm{p} / \mathbf{n}^{+}$) when $\phi_{\mathrm{n}} \geq 8 \times 10^{12} \mathrm{n} / \mathrm{cm}^{2}$ and the overall field profile is that of a $\mathrm{p}^{+} \mathrm{n} / \mathrm{i} / \mathrm{p} / \mathrm{n}^{+}$structure with field being controlled by the deep levels that cross the Fermi level which is pinned near the midgap. We note also there is very little flatband voltage shift in the MOS structures afrter extensive neutron irradiation, indicating minimal ionizing damage to the oxides. Oxygen concentration has been found to play a minimum role in the type inversion problem.

Although at low neutron fluences $\left(\phi_{\mathrm{a}}<10^{13} \mathrm{n} / \mathrm{cm}^{2}\right)$, oxygen concentration has been found to have little effect on the detector leakage current (or damage coefficient $\alpha$ ), a high concentration of oxygen may be helpful in a higher neutron fluence $\left(\phi_{\mathrm{n}}>10^{13} \mathrm{n} / \mathrm{cm}^{2}\right)$ domain to getter vacancies $(\mathrm{O}-\mathrm{V}$ formation) and therefore lower the detector leakage current. 


\section{LEAKAGE CURRENT VS $\mathbf{N}$ FLÚENCE WACKER $N(1,1,1)$ Kohm-om $20 \mathrm{C}$}

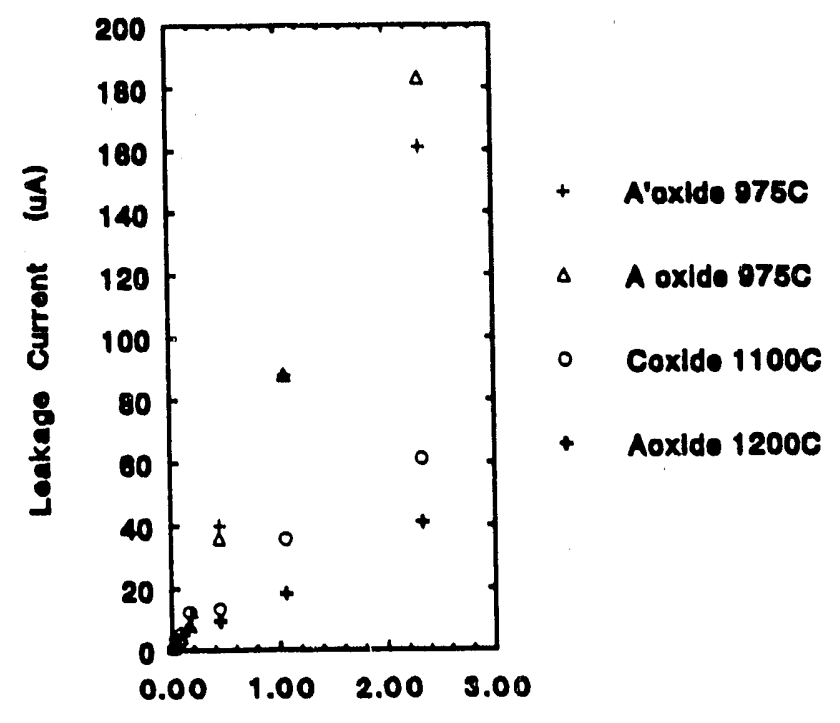

FluoncelXE14 $\mathrm{n} / \mathrm{cm} 2)$

Fig. 12. Detector leakage current as a function of neutron fluence with various oxidation thermal process conditions as parameter.

\section{ACKNOWLEDGMENTS}

We are pleased to thank $R$. Beuttenmuller and Wei Chen for their help and care in developing detectors for irradiation. Helpful discussions with F. John Walter, G. Lindstroem and E. Fretwurst are also gratefully acknowledged.

\section{REFERENCES}

[1] H. W. Kraner, Z. Li, and K. V. Pösnecker, "Fast Neutron Damage in Silicon Detectors," Nucl. Instrum. Methods A279, 266-271, (1989).

[2] G. Lindström, E. Fretwurst, H. Herdan, M. Rollwagen, P. Thomeen, and R. Wunstorf, "Radiation Damage Effects in Silicon Detectors," DESY 89-105, August (1989).

[3] H. Dietl, T. Gooch, D. Kelsey, R. Klanner, A. Loffler, M. Pepe, and F. Wickens, "Radiation Damage in Silicon Strip Detectors," Nucl. Instrum. Methods A253, 460-466, (1987).

[4] H. W. Kraner, "Radiation Damage in Silicon Detectors," Nucl. Instrum. Methods 225, 615-618, (1984).

[5] Z. Li and H. W. Kraner, "Studies of Frequency Dependent C$V$ Characteristics of Neutron Irradiated $P^{+}-n$ Silicon Detectors," presented at the 1990 IEEE Nuclear Science Symposium, Arlington, VA, October 23-27, IEEE Trans. Nucl. Sci. 38 (2), 244-250 (1991).

[6] W. Dabrowski, K. Korbel, and A. Skodzen, "Fast Neutron Damage of Silicon PIN Photodiodes," Nucl. Instrum. Methods A301, 288-294 (1991).

[7] E. Fretwurst, H. Herdan, G. Lindström, V. Pein, M. Rollwagen, H. Schatz, P. Thomsen, and R. Wunstorf, "Silicon Detector Developments for Calorimetry: Technology and Radiation Damage," Nucl. Instrum. Methods A288, 1-12 (1990).

[8] G. Lindstrom, M. Benkert, E. Fretwurst, T. Schulz and R. Wunstorf, "Radiation Effects in Si Detectors and Calorimeter Considerations," Proc. of the International Conference on Calorimetry in High Energy Physics, Fermi Laboratory, Batavia, IL, Oct. 29 - Nov. 1, 1990, eds. D. F. Anderson, M. Derrick, H. E. Fisk, A. Para, and C. M. Sazama (World Scientific, Singapore), 467-476 (1991).

[9] Zheng Li and H. W. Kraner, "Measurements of Possible Type Inversion in Silicon Junction Detectors by Fast Neutron Irradiation, " BNI,-46210, September 1991.

[10] S. D. Brotherton and P. Bradley, "Defect Production and Lifetime Control in Electron and $\gamma$-irradiated Silicon," J. Appi. Phys. 53 (8), 5720 (1982).

[11] E. H. Nicollian and J. R. 3rews, "MOS (Metal Oxide Semiconductor) Physics and Technology," (John Wiley \& Sons, New York), 144 (1982).

[12] G. Hall, private communication, 1991.

[13] Zheng Li and H. W. Kraner, "Changes in Electrical Properties of High Resistivity Silicon Caused Fast Neutron Damage," Proceedings of the Third Workshop on Radiation-Induced and/or Process-Related Electrically Active Defects in Semiconductor-Insulator Systems, A. Reisman, ed., Research Triangle Park, NC, September 10-13, 1991, p. 59-72 (1991).

\section{DISCLAIMER}

This report was F:epared as an account of work sponsored by an agency of the United States Government. Neithir the United States Government nor any agency thereof, nor any of their employees, makes any warranty, express or implied, or assumes any legal liability or responsibility for the accuracy, completeness, or usefulness of any information, apparatus, product, or process disclosed, or represents that its use would not infringe privately owned rights. Reference herein to any specific commercial product, process, or service by trade name, trademark, manufacturer, or otherwise does not necessarily constitute or imply its endorsement, recommendation, or favoring by the United States Government or any agency thereof. The views and opinions of authors expressed herein do not necessarily state or reflect those of the United States Government or any agency thereof. 

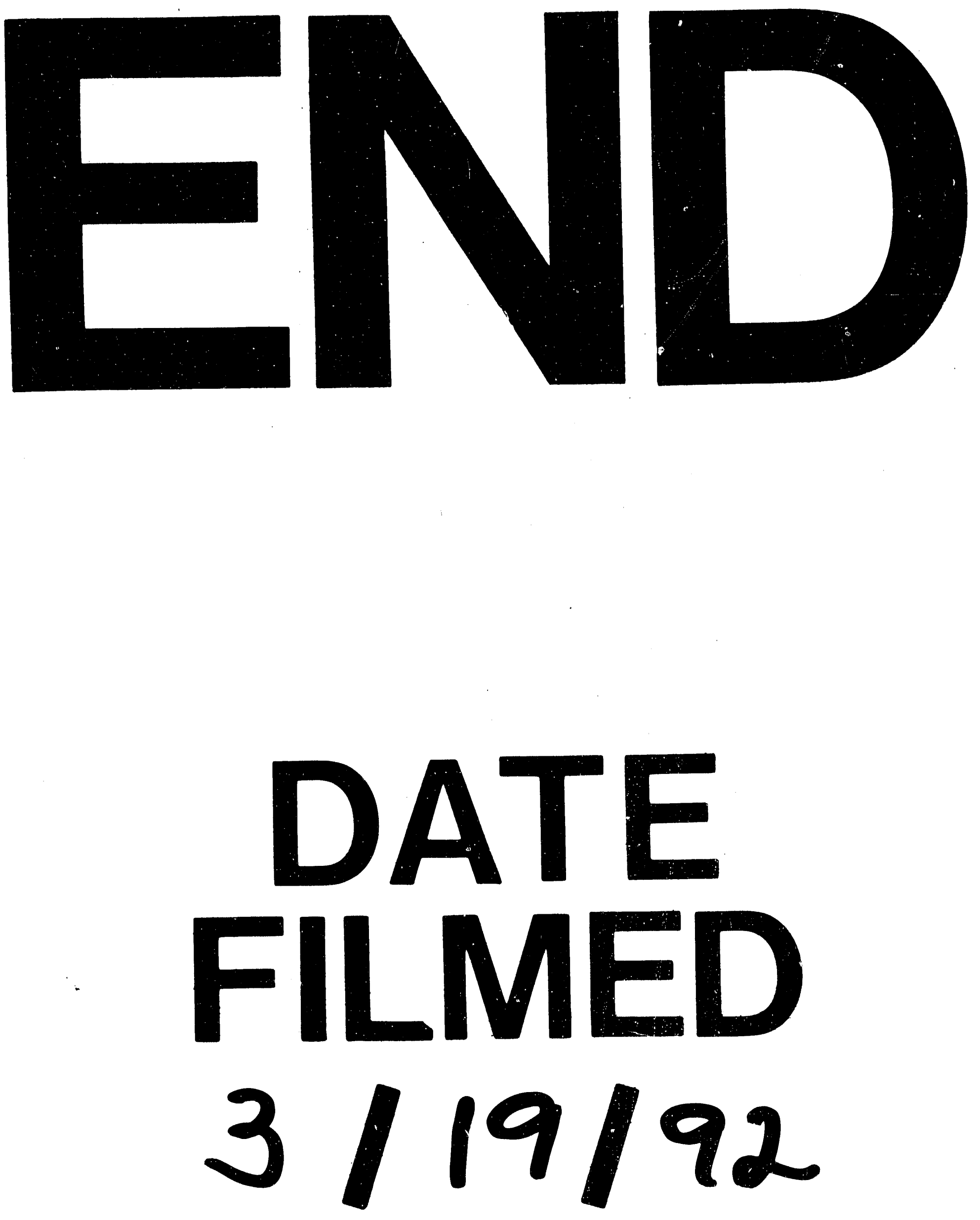

I 
